UDC 378:811.111

DOI:

Liudmyla Lozynska, Ph.D.(Pedagogy),Associate Professor of the Foreign Languages for Specific Purpose Department,

Donetsk Vasyl Stus National University

Nataliia Ishchuk, Ph.D.(Pedagogy), Associate Professor of the Foreign Languages for Specific Purpose Department,

Donetsk Vasyl Stus National University

Alina Ferri, Ph.D.(Pedagogy), Associate Professor of the

Foreign Languages Including Latin and Medical Terminology Department, Vinnytsya Mykola Pyrohov Memorial National Medical University

Olga Tsihotska, Ph.D.(Pedagogy), Associate Professor of the Foreign Languages including Latin and Medical Terminology Department, Vinnytsya Mykola Pyrohov Memorial National Medical University

\title{
EXPERIENCE OF USING INFORMATION AND COMMUNICATION TECHNOLOGIES IN FOREIGN LANGUAGE TEACHING
}

The article considers the use of information and communication technologies (ICT) in foreign language teaching, the advantages and disadvantages of their usage. ICT encompasses a set of technological tools and resources that are used to communicate, create, distribute, store, and manage information. Currently, there are many opportunities for the use of ICT in foreign language classes: multimedia textbooks and electronic dictionaries, educational programs, grammar and communication tasks on the Internet, search and research on the Internet, copyright teacher programs, etc. Due to the growing need to expand the list of resources that allow for effective language learning, it becomes necessary to consider various resources in terms of their usefulness and functionality. Information and communication technologies are considered from the point of view of the main types of educational tasks: phonetics, vocabulary, reading, listening, speaking, grammar, computer diagnostic tests. Taking into account all the positive and negative consequences of the use of ICT, it was concluded that they are effective when combined with traditional methods and contribute to the qualitative formation of skills and abilities of students. The use of ICT in foreign language lessons - is one of the types of organization of the educational process. Particularly successful teaching a foreign language began to develop with the popularization of ICT. This increases interest in the subject, enhances motivation, creates conditions for independent work and a comfortable learning environment. ICT aids for a better study of a foreign language. It is a tool that helps teachers to improve the process of acquiring knowledge. It is difficult to imagine the modern educational process without the use of new information and communication technologies and various computer programs. They provide an opportunity to work independently, evaluate students' skills acquired in the learning process.

Keywords: information and communication technologies (ICT); foreign language teaching; phonetics; vocabulary; reading; listening; speaking; grammar; computer diagnostic tests; the advantages and disadvantages of using ICT.

Ref. 11.

Людмила Лозинська, кандидат педагогічних наук, доцент кафедри іноземних мов професійного спрямування Донеиького національного університету імені Василя Стуса Наталія Іщук, кандидат педагогічних наук, доцент кафедри іноземних мов професійного спрямування Донецького національного університету імені Василя Стуса

Аліна Феррі, кандидат педагогічних наук, доцент кафедри іноземних мов з курсом латинської мови та медичної термінологї Вінницького національного медичного університету імені М. І. Пирогова

Ольга Ціхоцька, кандидат педагогічних наук, доцент кафедри іноземних мов з курсом латинської мови та медичної термінологіі Вінницького національного медичного університету імені М. І. Пирогова

\section{ДОСВІД ВИКОРИСТАННЯ ІНФОРМАЦІЙНО-КОМУНІКАЦІЙНИХ ТЕХНОЛОГІЙ У НАВЧАННІ ІНОЗЕМНИХ МОВ}

У статті розглядається використання інформаційно-комунікаиійних технологій (IКT) у навчанні іноземних мов,їх переваги та недоліки. IКТ охоплює набір технологічних інструментів та ресурсів, які 


\section{EXPERIENCE OF USINGINFORMATIONAND COMMUNICATIONTECHNOLOGIES IN FOREIGN LANGUAGE TEACHING}

використовуються для спілкування, створення, розповсюдження, зберігання їх інформації і управління нею. Сьогодні існує багато можливостей для використання IКТ на заняттях іноземних мов: мультимедійні підручники та електронні словники, освітні програми, граматичні та комунікативні завдання в Інтернеті, пошук $і$ дослідження в Інтернеті, авторські програми викладачів тощзо. Існує необхідність розщирення переліку ресурсів, шзо допомагають ефективно вивчати мову, ураховування різних ресурсів з точки зору їх корисності та функціональності. Інформаційно-комунікачійні технології розглядаються з точки зору основних видів навчальних завдань: фонетики, лексики, читання, аудіювання, говоріння, граматики, комп'ютерних діагностичних тестів. Беручи до уваги всі позитивні та негативні наслідки використання ІКТ, було зроблено висновок, щуо вони ефективні в поєднанні з традиційними методами та сприяють якісному формуванню вмінь і навичок володіння іноземною мовою. Це інструмент, який допомагає викладачам вдосконалити процес набуття знань. Важко уявити сучасний навчальний проиес без використання нових інформаційнокомунікаційних технологій та різноманітних комп'ютерних програм. Вони дають можливість самостійно працювати, оцінювати навички здобувачів освіти, набуті в прочесі навчання.

Ключові слова: інформачуійн-комунікачійні технології (IКТ); викладання іноземних мов; фонетика; словниковий запас; читання; слухання; говоріння; граматика; комп 'ютерні діагностичні тести; переваги та недоліки використання IКT.

I ntroduction. Methods of teaching foreign languages are a field of pedagogy that is constantly evolving, which can no longer exist without the use of information and communication technologies (ICT). The development of information and communication technologies has significantly influenced the theory and practice of teaching foreign languages.

Language education is an area where open-access resources, online courses, virtual classrooms, and social networks based on ICT are being increasingly used to give learners access to information, promote interaction and communication, and enhance digital literacy skills.

Analysis of key studies and publications. ICT encompasses a set of technological tools and resources that are used to communicate, create, distribute, store, and manage information.

In our previous studies, we defined ICT as "a systematic set of psychological and pedagogical procedures that include a specific selection and arrangement of didactic forms, methods, techniques, and conditions for computer-based learning" [1]. We also agree with F. Rakhimova (2019) who claims that ICT is the innovation that comprises gathering, processing, storing, and presenting information, and also involves collaboration and communication [10].

According to N. Rozhkova (2014), the use of ICT in teaching a foreign language makes learning professionally oriented, enables students to use internet resources, facilitates project work, namely due to creation of PowerPoint presentations, involves acquiring different skills through educational software, provides distance learning, etc. [3].

ICT boosters learning foreign languages because they:

- have become an integral part of the learning process in general;

- enable a teacher to use a wider range of activities for building students' language skills, help to integrate them into a single experience;

- are aimed at developing the four basic language skills along with critical thinking, attention, logic, etc.;

- provide access to authentic materials;

- increase students' cognitive activity;

- motivate to learn a foreign language due to new forms of work and involvement in the priority area of scientific and technological progress;

- support cognitive and socio-cognitive theories of language teaching;

- help to focus on one particular part of the lesson (pronunciation, vocabulary, etc.);

- effectively create a continuum between learning and the rest of social and professional experience;

- improve skills of students' autonomous work in information databases;

- help to exercise control through testing and a system of questions for self-control $[1 ; 3 ; 4 ; 5 ; 9 ; 10]$.

However, learning with ICT does not solve all problems, and new technologies cannot completely replace the traditional teaching methods.

Many teachers have several concerns about the introduction of technology in teaching. G. Harrison (2020) names the three most common:

1. Technology isolates - interaction with students is limited.

2. Teachers get a "desktop", and the essence of teaching is somewhat lost.

3 . The growth of technologies, in particular artificial intelligence (AI), will soon lead to the dismissal of teachers [8].

Among the disadvantages of using ICT is the risk of obtaining inaccurate information from the Internet in the absence of verification of the source. However, not all foreign language teachers have a sufficient level of computer literacy to create their own highquality original educational computer products. Very often foreign language teachers simply do not have enough time to create information and communication products as it takes a lot of time. Although today you can find a variety of developments online, the self- 


\section{EXPERIENCE OF USING INFORMATIONAND COMMUNICATIONTECHNOLOGIES}

INFOREIGNLANGUAGE TEACHING

created tool has many advantages. After all, the teacher creates a linguistic and didactic tool for the audience with the appropriate level of knowledge of a foreign language and certain needs, "predicts" how this product can be used and what will be the degree of its effectiveness.

There is also a real threat of turning the teaching process into a formal mechanical reproduction of facts using a spectacular video sequence. Often the use of large amounts of ICT materials during the class harms other forms of work. Such classes turn into a monologue of the teacher, with the students' feedback being lost.

We agree with the opinion of M. Myastkovska, I. Kobylyanska, N. Vasazhenko (2019) that excessive use of ICT reduces live communication between teachers and students. As a result, future professionals do not develop their teamwork skills essential for active and efficient communication with colleagues, participation in discussions, sharing opinions and arguments, etc. [2].

Currently, there are many opportunities for the use of ICT in foreign language classes: multimedia textbooks and electronic dictionaries, educational programs, grammar and communication tasks on the Internet, search and research on the Internet, copyright teacher programs, etc. The wide application of multimedia technologies for developing learners' foreign language skills creates favorable conditions for significantly reforming the existing system of professional education.

Due to the growing need to expand the list of resources that allow for effective language learning, it becomes necessary to consider various resources in terms of their usefulness and functionality.

The article aims at analyzing the theoretical scientific achievements on the problem of using information and communication technologies and to demonstrate experimentally tested ways of their use in the process of learning foreign languages.

Presentation of the main research material. Information and communication technologies can be considered from the point of view of the main types of educational tasks.

Phonetics. With the help of information and communication technologies, the technique of visualizing pronunciation is often used. Due to multimedia, students can listen to native speakers as much as necessary. With a microphone and automatic pronunciation control system, foreign language learners can improve their phonetic skills (including those used in programs such as Duolingo, Reverso, etc.).

Abbas Pourhosein Gilakjani (2018) notes that ICT are different from traditional teaching methods. They provide teachers with a better and enjoyable educational environment, offer them an interactive environment, help them gain acceptable pronunciation that is closer to that of native speakers, and also enhance the quality of their pronunciation instruction. The increasing application of ICT does not imply that traditional methods should be regarded as obsolete and inefficient. It brings about better results than the traditional methods [7].

Yolanda Joy Calvo Benzies (2017) divides the tools currently available into three main groups: a) programs with activities to help students improve their pronunciation at a segmental and suprasegmental level, like Pronunciation Power, Streaming Speech, Connected Speech, Learn to Speak Clearly in English, Berlitz English Pronunciation Programme, Teach Yourself English Pronunciation, TP, FluSpeak, Clear Speech, Integral Inglüs, or Tell me More Kids; b) programs and websites which convert a text into phonetic transcription like Photransedit, the Phonemic Chart Keyboard, Lingorado, IPA Online Keyboard; and, thirdly, c) recording programs that allow students to record themselves speaking, some of which transcribe the spoken message into written form (Recorder Pro, Dragon Dictate, Audacity or Wave Pad) [6].

Marla Tritch Yoshinda (2018) focuses on the following pedagogical tasks that are a common part of pronunciation teaching: 1 . Providing a pronunciation model. Students need to hear examples of the pronunciation of individual sounds and words, and also examples of longer stretches of meaningful connected speech. Technical tools can supplement the model that teachers themselves provide. 2. Recording students' pronunciation practice. Learners can benefit from recording and listening to their pronunciation to help them develop the ability to self-correct. When this recording is done through apps or websites that make the recordings part of a creative project, motivation and interest can be increased. 3. Collecting and responding to students' recorded practice. Teachers often listen to learners' recordings and give feedback as a guide for future practice. This process can be simplified through technical tools. 4. Providing independent pronunciation practice [11].

Vocabulary. The attention to vocabulary learning can be explained by many reasons: the ability to communicate depends on the degree of vocabulary proficiency; skills in the use of lexical units underlie the types of speech activities like listening, reading, speaking, and writing.

The stages of learning new lexical units can include:

- introduction of new lexical units;

- semantization; 
- practice of pronunciation and control of understanding the meaning of new lexical units;

- memorizing new words and expressions;

- training in the use of new lexical units.

The work on the formation of lexical skills at a particular stage depends on the teaching method used by the teacher in the classroom. Following the modern communicative teaching methods in a foreign language, new lexical units should be introduced in real communication situations and correspond to the issue.

According to the traditional methods of teaching foreign languages, reading aloud and translating texts are efficient in vocabulary acquisition practice. However, this method proved to be ineffective in learning a foreign language, because it does not help students achieve communicative competence.

The use of ICT intensifies vocabulary learning through diverse tasks and activities, for example, exercises in the form of a game for making sentences (programs for selecting synonyms and antonyms, automatic dictionaries); exercises to fill in the gaps (an erroneous answer entails the student's transition to the next task or proposal with the display of the correct option); exercises in the form of crosswords, where when writing a word, the wrong letter is highlighted in a different color.

$A B B Y Y$ Lingvo is one of the computer programs and family of electronic dictionaries for successful learning of vocabulary. It is one of the most popular software that has many advantages:

- available in different technological realization and for different usage scenarios;

- more than 1200000 words' entries;

- 19 general and special dictionaries;

- pronunciation of 5000 English words by a native speaker;

- English grammar dictionary;

- on-line translation from the Internet and any Windows applications;

- creation and updating of user's dictionaries;

- full-text search;

- tips for translation and examples of usage;

- additional free dictionaries.

Another useful means of learning new vocabulary is Reverso. It specializes in machine translation and language learning assistance. The site offers online dictionaries, contextual translation, spellchecking, synonym search, and grammar.

There are several vocabulary game-based learning programs. They add some element of diversity to the language learning process. For example, Quizlet is an online service that helps you quickly memorize English vocabulary.

The question of the appropriateness of the use of electronic dictionaries in the translation of texts is widely discussed among teachers of foreign languages and scientists. Working with a dictionary is to a large extent an integral part of students' independent work. The ability to use a dictionary does not come automatically, it must be acquired.

This skill is a combination of a large number of operations performed by a person working with a bilingual dictionary. These include: searching for a word alphabetically; search for a word to form the plural form of nouns; word search to find the meaning of polysemantic words; search for the meaning of a word in a dictionary entry that combines several words with a common first root; word search to determine the forms of verbs; word search to transform words and other points. Many electronic dictionaries have the function of speaking a word, which allows students to understand how to pronounce a particular word correctly.

Reading. The benefits of reading using ICT include:

- improvement of cognitive development and language skills (it helps to think and understand, which is the essence of cognitive development);

- close relational bonding;

- increased attention span;

- improved creativity.

Spreeder Online is a free app dedicated to helping you to improve speed reading skills. In today's world, with so much information at our fingertips thanks to the World Wide Web, speed reading is a more useful skill than ever before. The tasks aimed at training fast reading with general coverage of the content. Multiple-choice questions may be asked after each page or all of the text.

New in Levels is an application to improve English naturally and fast with articles. Each article is written in 3 levels. Level 1 has 1000 of the most important words. Level 2 has 2000 of the most important words. Level 3 has 3000 of the most important words.

Listening - control of the correct understanding of the content of the listened text, the formation of listening skills.

Different videos and songs are often used to better listening skills.

Nowadays, TED Talks have become the most popular talks. TED (Technology, Entertainment, Design) is a universal online platform with many conferences of leading experts in the fields of science, art, design, politics, culture, business, global issues, technology, and entertainment. The mission of the conference is to spread unique ideas ("ideas worth spreading"). Recordings of the most distinguished speakers can be found on the official TED.com website. Currently over 1,500 selected lectures with 


\section{EXPERIENCE OF USING INFORMATIONAND COMMUNICATIONTECHNOLOGIES}

INFOREIGNLANGUAGE TEACHING

translations in various languages are available on the website. All videos are released under the Creative Commons BY-NC-ND license, which allows free distribution.

The system of working with such a site, as with any other audio text, boils down to the following scheme: "sound - text-sound" (j\& $+\mathrm{T}+\mathrm{j} \&)$. First, students are encouraged to watch a video without subtitles and grasp the main meaning. This is followed by a detailed analysis of the text using the subtitles provided, as well as, if the teacher wishes, with the help of additional vocabulary and grammar exercises. After that, the video is re-watched, during which auditory-visual synthesis takes place, the simultaneous broadcast of sound and images contributes to the development of speech perception skills and stimulates oral communication of trainees during further discussion of the video material.

The illusion of "complete immersion" in an authentic environment is created. Due to this feeling, forgotten knowledge of grammar and vocabulary begins to activate, and the melody of the language itself is caught, which is also important when teaching speaking.

Learning is most successful and enjoyable when students are relaxed.

With LyricsTraining, they will not only quickly improve their listening comprehension but also enlarge vocabulary by learning new words and expressions, improving reading comprehension, and boosting grammar skills. With Lyricstraining students forget about studying and memorizing endless vocabulary lists for a moment.

Speaking - control of pronunciation, formation of phonetic speaking skills; organization of individual work, or in pairs and small groups.

Learning English-BBC, British Council Online Courses, Talk English, TED - all these sites help learn English and improve pronunciation, grammar, and vocabulary knowledge as well as speaking skills. Teachers can successfully use the materials of these courses for classes.

But there is one more technique for training speaking - presentation. Presentation is one of the means to train speaking skills. It has some properties that distinguish them from traditional means:

- software compatibility - the ability to use objects from other programs, for example, from MS Office, Paint;

- interactivity - the ability to respond to actions;

- multimedia - the use of a set of effects for the presentation of information (text, sound, graphics, animation, video) by one technical means;

- complexity (options for managing the process of presenting information);
- discreteness - autonomy, logical completeness of an individual slide or group of slides;

- availability of technical tools.

Grammar. The use of information and communication technologies in a grammar lesson is possible when studying almost any topic. With the help of information and communication technologies, it is much more interesting to control the level of formation of grammatical skills. Translation - the formation of lexical and grammatical translation skills; control of the correctness of the translation, provision of reference, and information support (use of automatic dictionaries, glossaries, systems for selecting antonyms and synonyms).

Automatic translation systems are constantly being improved, but they do not always provide a highquality and adequate translation. The teacher's task is to explain that automatic translation systems can produce results of varying quality and degree of reliability. In addition, the teacher can allow students to use such systems when completing assignments to show the features, advantages, and disadvantages of working with automatic translation systems.

It is unacceptable to use electronic translators in tests or exams since instead of their knowledge, students demonstrate a more or less successful translation performed by a computer. The ability to receive a ready-made translation of a text for educational purposes with the help of an electronic dictionary can rather be attributed to negative factors. In this case, easier labor means an exception the need to perform a set of mandatory mental operations in the translation technique, and, therefore, the process of translation activities is simply replaced by the finished product. Electronic translation today is not perfect enough to provide an impeccably accurate translation. Inaccuracies and errors lead to a distortion of the meaning.

Grammarly (the program to improve your writing and make fewer mistakes). Being more than just a spellchecker, the software also highlights grammar mistakes and explains them. Grammarly is an online service based on artificial intelligence to help you write texts in English. The service helps to write in English more efficiently and provides recommendations regarding correctness, clarity, fun, and tone of the message. Grammarly is available in multiple interfaces. Service tips are grouped into 4 categories: correctness (grammatical, spelling, punctuation, and other errors), clarity (conciseness and comprehensibility), fun (vocabulary and variety), presentation of information (formality, politeness, confidence).

To check reading, listening, speaking, and writing skills computer diagnostic tests are often used. The 


\section{EXPERIENCE OF USING INFORMATIONAND COMMUNICATIONTECHNOLOGIES INFOREIGNLANGUAGE TEACHING}

use of computer diagnostic tests in the classroom allows the teacher in a short time to get an objective picture of the level of assimilation of the material studied by all students and to correct it promptly. It is possible to choose the level of difficulty of the task for a particular student. It is important that immediately after the test (when the information has not lost its relevance) the student receives an objective result indicating errors, which is impossible, for example, in an oral interview.

During the lockdown computerized control is often used in the process of language teaching. The advantages of computerized control include the following: multilevel control system; the possibility of individualized control; massiveness and regularity; objectivity and flexibility of assessment; creation of databases on the course of training; automated statistical processing of results.

Thus, the introduction of information and communication technologies contributes to the achievement of the main goal of education modernization - improving the quality of education, increasing its availability, ensuring the harmonious development of the individual. In classes where information and communication technologies are used on an ongoing basis, students demonstrate a higher level of motivation. The use of information and communication technologies helps to increase the efficiency of mastering a foreign language.

Conclusions and prospects for further research. The use of ICT in foreign language teaching has become an effective means of achieving quality results. The use of at least fragments of ICT in the learning process significantly increases its effectiveness.

Taking into account the abovementioned benefits and drawbacks of ICT in education, we can conclude that they are effective when combined with traditional methods, sticking to the principles of methodological expediency and validity. Apart from being an efficient language learning tool, ICT contribute to the qualitative building of students' skills and abilities.

Overall, the study evidences that even though ICT are being increasingly used in learning foreign languages, a teacher must be able to utilize them wisely, so that they fit organically into the system of education. Such a mode of training boosts students' motivation and desire to acquire foreign language skills. The use of ICT in foreign language lessons increases learner's interest in the subject, enhances motivation, creates conditions for independent work and a comfortable learning environment. The tool helps learners acquire the four basic language skills as well as boosts their own mental and cognitive abilities and skills. ICT also enable students to work independently and evaluate their progress in learning foreign languages.

Further research is needed into the advantages and disadvantages of using ICT in distance learning foreign languages during the lockdown.

\section{REFERENCES}

1. Іщук Н. Ю. Використання інформаційнокомунікаційних технологій у навчально-виховному процесі як соціальна і психолого-педагогічна проблема. Инновационные технологии в образовании: Материаль III научнопрактической конференции. Симферополь, 2006. C. 237-241.

2. Мястковська М., Кобилянська I., Васаженко Н. Аналіз недоліків інформаційнокомунікаційних технологій у закладах вищої освіти. URL: https://pedbezpeka.vntu.edu.ua/ index.php/pb/article/view/98

3. Рожкова Н. Використання інформаційнокомп'ютерних тухнологій як інноваційного методу в навчанні іноземних мов. URL: https://core.ac.uk/ download/pdf/83099886.pdf

4. Роман Л. А. Інформаційні технології як інновація у викладанні української мови як іноземної. URL: https://seanewdim.com/uploads/3/ 4/5/1/34511564/roman l.a._information technology as an innovation in teaching ukrainian as a foreign language.pdf

5. Троцко А., Короткова Ю. Застосування інформаційно-комунікаційних технологій у процесі навчання іноземних мов: досвід України та Греції. URL: https://www.researchgate.net/publication/ $\underline{331333477}$

6. Benzies Yolanda Joy Calvo. Contributions of new technologies to the teaching of English pronunciation. URL: file://D:/Downloads/Dialnet ContributionsOfNewTechnologiesToTheTeachingOfEngli6206374\%20(1).pdf

7. Gilakjani Abbas Pourhosein. Teaching the pronunciation of English with computer technology: a qualitative study. URL: http://ijreeonline.com/article1-119-en.pdf

8. Harrison Graeme. English teaching and learning during the Covid crisis: online classes and upskilling teachers. URL: https://www.cambridgeenglish.org/ blog/authors/graeme-harrison/

9. Negoescu Alina, Bostina-Bratu Simona. Teaching and learning a foreign language with ICT. URL: https://www.researchgate.net/publication/ 305677313 Teaching and Learning Foreign Languages_with_ICT

10. Rakhimova Firusa Shavkatovna. Methods of using information technology in teaching foreign languages. URL: https://cyberleninka.ru/article/n/ 
methods-of-using-information-technology-inteaching-foreign-languages

11. Yoshinda Marla Tritch. Choosing Technology Tools to Meet Pronunciation Teaching and Learning Goals. URL: https://files.eric.ed.gov/fulltext/ EJ1174226.pdf

\section{REFERENCES}

1. Ishchuk, N. Yu. (2006). Vykorystannia informatsiino-komunikatsiinykh tekhnolohii $\mathrm{u}$ navchalno-vykhovnomu protsesi yak sotsialna i psykholoho-pedahohichna problema [The use of information and communication technologies in the educational process as a social and psychologicalpedagogical problem]. Innovatsionnye tekhnologii v obrazovanii: Materialy III nauchnoprakticheskoy konferentsii - An innovative technologies in education: Proceedings of the $3 \mathrm{rd}$ Scientific-Practical Conference. Symferopol, pp. 237-241. [in Russian].

2. Miastkovska, M., Kobylianska, I. \& Vasazhenko, N. Analiz nedolikiv informatsiinokomunikatsiinykh tekhnolohii u zakladakh vyshchoi osvity [An analysis of the shortcomings of information and communication technologies in higher education institutions]. Available at: https://pedbezpeka. vntu.edu.ua/index.php/pb/article/view/98 [in Ukrainian].

3. Rozhkova, N. Vykorystannia informatsiinokompiuternykh tukhnolohii yak innovatsiinoho metodu $\mathrm{v}$ navchanni inozemnykh mov [The use of information and computer technologies as an innovative method in teaching foreign languages]. Available at: https:// core.ac.uk/download/pdf/83099886.pdf [in Ukrainian].

4. Roman, L. A. Informatsiini tekhnolohii yak innovatsiia u vykladanni ukrainskoi movy yak inozemnoi [Information technologies as an innovation in teaching Ukrainian as a foreign language]. Available at: https://seanewdim.com/uploads/3/4/5/1/ 34511564/roman 1.a. information $t$ echnology as_an_innovation_in teaching_ukrainian_as a foreign language.pdf [in Ukrainian].

5. Trotsko, A. \& Korotkova, Yu. Zastosuvannia informatsiino-komunikatsiinykh tekhnolohii u protsesi navchannia inozemnykh mov: dosvid Ukrainy ta Hretsii [Application of information and communication technologies in the process of learning foreign languages: the experience of Ukraine and Greece]. Available at: https://www.researchgate.net/ publication/331333477 [in Ukrainian].

6. Benzies Yolanda Joy Calvo. Contributions of new technologies to the teaching of English pronunciation. Available at: file:///D:/Downloads/Dialnet Contributions OfNew Technologies To TheTeachingOfEngli6206374\%20(1).pdf [in English].

7. Gilakjani Abbas Pourhosein. Teaching the pronunciation of English with computer technology: a qualitative study. Available at: http://ijreeonline.com/ article-1-119-en.pdf [in English].

8. Harrison Graeme. English teaching and learning during the Covid crisis: online classes and upskilling teachers. Available at: https:// www.cambridgeenglish.org/blog/authors/graemeharrison/ [in English].

9. Negoescu Alina, Bostina-Bratu Simona. Teaching and learning a foreign language with ICT. Available at: https://www.researchgate.net/ publication/305677313 Teaching and Learning Foreign_Languages_with_ICT [in English].

10. Rakhimova Firusa Shavkatovna. Methods of using information technology in teaching foreign languages. Available at: https://cyberleninka.ru/article/ n/methods-of-using-information-technology-inteaching-foreign-languages [in English].

11. Yoshinda Marla Tritch. Choosing Technology Tools to Meet Pronunciation Teaching and Learning Goals. Available at: https://files.eric.ed.gov/fulltext/ EJ1174226.pdf [in English].

Стаття надійшла до редакції 23.03.2021

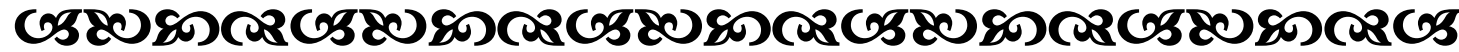

“Dва основні надбання дюдської природи - ие розум і мірқування”.

$$
\begin{array}{r}
\text { Tлутарх } \\
\text { давньогреиький письменник }
\end{array}
$$

“Усе своє життя старанно навчайся. Кожен день ставай майстернішим, ніж ти був за день до цього, а на наступний день - майстернішим, ніж сьогодні. Вдосқоналення не має кіния".

\section{G5808nc2058080}

